\title{
José Carlos de Almeida Basques, 1941-2009
}

"Quando o excesso de seiva levanta a planta jovem a escalar o espaço, só à custa de troncos alheios logra ella chegar à altura - faltando-lhe as raízes, que sómente os annos soem improvisar, restar-lhe-á apenas o epiphytismo das orchideas"

\section{João Guimarães Rosa, discurso de formatura na Faculdade de Medicina da UFMG, 1930}

Dr. José Carlos Basques, como era mais conhecido, nasceu em Sabará (MG), em 1941, numa família numerosa. Eram 14 irmãos, e foi com muito esforço que, em 1965, ele se formou em medicina pela Faculdade de Medicina da Universidade Federal de Minas Gerais (FM/UFMG). Tinha muito orgulho da sua origem sabarense, mineiro de raiz que era, assim como da sua ascendência basca, pelo avô paterno.

Em uma época de pioneirismo da patologia clínica, seu espírito empreendedor o guiou para a área laboratorial, primeiramente, atuando no laboratório do Hospital do Instituto de Previdência do Servidor do Estado de Minas Gerais (IPSEMG) e, também, com o Dr. Orion de Bastos, no Laboratório de Hematologia e Patologia Clínica, depois Hemoclínica. Comparecia, voluntariamente, aos sábados ao Laboratório do IPSEMG para preparar os reagentes a serem utilizados no setor de química, junto com o Dr. Geraldo Lustosa Cabral, outro grande parceiro nas atividades de análises clínicas.

Da otimização desses procedimentos nasceram idéias que se tornaram o embrião do que viria a ser a Labtest, empresa da qual era sócio-fundador e diretor-presidente. Fundada em 1971, em sociedade com o Dr. Geraldo Lustosa, a Labtest Diagnóstica S/A foi uma das primeiras empresas nacionais a desenvolver, produzir e comercializar conjuntos diagnósticos para laboratórios clínicos. Sob sua administração serena, porém firme, tornou-se uma das maiores e mais conceituadas empresas do país e da América Latina.

Em 1990, em conjunto com mais outras oito empresas mineiras do setor de biotecnologia, o Dr. Basques criou a Fundação Biominas e, desde então, foi membro de seu conselho curador, para o qual contribuiu com sua grande experiência empresarial e do setor laboratorial, sempre de forma respeitosa, ética e colaborativa. Por seu desempenho e espírito empreendedor, em 1999 recebeu, da Federação das Indústrias do Estado de Minas Gerais, o honroso título de "Construtor do Progresso".

Em 1974 o Dr. Basques obteve o título de especialista em patologia clínica/medicina laboratorial, passando a atuar, continuamente, como associado muito ativo da Sociedade Brasileira de Patologia Clínica/Medicina Laboratorial (SBPC/ $\mathrm{ML})$, sendo conferencista e membro da comissão científica de diversos congressos da SBPC/ML e apresentando palestras em jornadas, simpósios e cursos presenciais e à distância realizados pela sociedade. Foi também membro da Comissão de Acreditação de Laboratórios Clínicos (CALC), que definiu a norma do Programa de Acreditação de Laboratórios Clínicos (PALC), e participou do conselho editorial deste Jornal Brasileiro de Patologia e Medicina Laboratorial (JBPML).

Em 2006, participou da PALC, que resultou na versão atualmente em uso e, em 2007, o Dr. Basques foi empossado como membro efetivo do conselho fiscal do Sindicato das Indústrias de Produtos Farmacêuticos e Químicos para Fins Industriais no Estado de Minas Gerais (SINDUSFARQ).

Sua exitosa trajetória como médico, pesquisador e empreendedor foi marcada, sobretudo, por sua conduta ética, sua dignidade e seu respeito pelo ser humano. Foi graças à sua incansável dedicação e ao espírito inovador e de colaboração que o Dr. José Carlos Basques tornou-se uma referência para o crescente desenvolvimento do setor de medicina laboratorial no Brasil.

Dr. José Carlos havia sido indicado para presidir o $43^{\circ}$ Congresso Brasileiro de Patologia Clínica/Medicina Laboratorial da SBPC/ML, a se realizar em Belo Horizonte em agosto próximo. O tema deste congresso, "Medicina laboratorial e segurança do paciente", foi escolhido por ele como forma de sinalizar aos profissionais de laboratório a grande importância de que se reveste hoje o lapidar princípio hipocrático primum non nocere. Seus cuidados para que $043^{\circ}$ Congresso fosse inesquecível tornam ainda maior não só a nossa responsabilidade, mas também a nossa motivação para continuarmos seu trabalho em prol de uma patologia clínica cada vez melhor.

Luisane Maria Falci Vieira Médica patologista clínica; coordenadora da Comissão Científica do 430 Congresso Brasileiro de Patologia Clínica/Medicina Laboratorial 